\title{
Magnetic field in coffee seed germination
}

\section{Campo magnético na germinação da semente de café}

\author{
Roberto Alves Braga Júnior ${ }^{1} \mathbb{D}$, Roberto Luiz de Azevedo ${ }^{2 *} \mathbb{D}$, \\ Renato Mendes Guimarães ${ }^{3}$, Leandro Vilela Reis ${ }^{3}$ [C
}

\author{
${ }^{1}$ Universidade Federal de Lavras/UFLA, Departamento de Engenharia/DEG, Lavras, MG, Brasil \\ ${ }^{2}$ Instituto Federal de Educação, Ciência e Tecnologia do Sul de Minas Gerais, Machado, MG, Brasil \\ ${ }^{3}$ Universidade Federal de Lavras/UFLA, Departamento de Agricultura/DAG, Lavras, MG, Brasil \\ ${ }^{*}$ Corresponding author: roberto.azevedo@ifsuldeminas.edu.br \\ Received in April 8, 2020 and approved in June 23, 2020
}

\begin{abstract}
The effective production of coffee seedlings faces many challenges, including seed germination. Therefore, a reduced seed germination period can be one of the most relevant contributions to enhance the testing and production of robust seedlings. The objective of this research was to evaluate the effects of a constant magnetic field on the germination of coffee seeds (Coffea arabica L.). The analyses were performed using a biospeckle laser (BSL) in conjunction with traditional seed viability tests. The coffee seeds were subjected to magnetic fields of constant intensity at values of $10 \mathrm{mT}$ and $28 \mathrm{mT}$ for a time interval of 6 days during their germination process. The embryo region was illuminated, and the images obtained by the BSL were processed. The activity levels of this region were compared with the data obtained using traditional physiological seed analysis. In addition to the results of BSL activity, the results of the seed analysis, such as isoenzymatic catalase (CAT), esterase (EST), superoxide dismutase (SOD), malate dehydrogenase (MDH) and endo- $\beta$-mananase, membrane integrity, germination, germination speed index (GSI), emergence speed index (ESI), and radicular protrusion levels, were obtained during the germination process. In conclusion, magnetic pretreatment with both intensities during the first six days of germination improved the permeability of the cellular membranes and advanced the activation of the antioxidant system, thus promoting faster and more uniform seed germination.
\end{abstract}

Index terms: Magnetism; breaking dormancy; BSL.

\section{RESUMO}

A produção de mudas de café para o plantio apresenta diversos entraves sendo talvez o longo período de germinação das sementes um dos principais. A minimização do intervalo de tempo de germinação traz inúmeros benefícios como, por exemplo, a disponibilização das mudas para plantio na melhor época do ano. Nesta pesquisa, objetivou-se avaliar os efeitos da aplicação de um campo magnético constante sobre a germinação de sementes de café (Coffea arabica L.). As análises foram realizadas por meio do Biospeckle Laser (BSL) consorciadamente aos testes tradicionais de viabilidade de sementes. As sementes de café foram submetidas a campos magnéticos de intensidade constante e valores de $10 \mathrm{mT}$ e $28 \mathrm{mT}$ por um mesmo intervalo de tempo de 6 dias durante seu processo de germinação em germinadores. Iluminou-se a região do embrião e as imagens obtidas pelo Biospeckle Laser foram processadas e, em seguida, os resultados dos níveis de atividade desta região foram posteriormente comparados com os dados obtidos pela análise fisiológica tradicional de sementes. Além dos resultados de atividade do BSL, foram obtidos resultados das análises de sementes durante o processo de germinação, tais como: isoenzimático - catalase (CAT), esterase (EST), superóxido dismutase (SOD), malato desidrogenase (MDH) e endoß-mananase -, integridade de membranas, germinação, índice de velocidade de germinação (IVG), índice de velocidade de emergência (IVE) e protrusão radicular. Concluiu-se que o pré-tratamento magnético com ambas intensidades durante os primeiros seis dias de germinação, propiciou uma melhora na permeabilidade das membranas celulares, uma ativação precoce do sistema antioxidantes, além de promover uma germinação mais rápida e uniforme das sementes.

Termos de indexação: Magnetismo; quebra de dormência; BSL.

\section{INTRODUCTION}

Currently, coffee plants are exploited for shorter time periods, and when they become older and less productive, they are replaced by new plants. The replacement of a coffee plant for a more efficient plant is a designated process of coffee renewal (Matiello; Garcia; Almeida, 2009). One of the largest obstacles for renewing coffee plants is the slow germination of coffee seeds, which greatly compromises the dynamics of this process. 
The slow germination of coffee seeds coupled with the quick loss of germination power creates situations in which the results of germination tests may no longer reflect the true physiological state of the seed to be planted (Dias; Silva, 1986), and their predisposition to pathogen attacks seriously impairs germination.

Eira et al. (2006) noted that the loss of germination power in coffee seeds is due to changes imposed on the structure of the cell membranes, with consequent loss in selective permeability though exposure to high or very low temperatures, variations in air moisture, and injuries to the seeds. In this sense, pregerminative treatments have been used as an alternative to increase germination uniformity and speed (Guimarães et al., 2013).

Recent studies have addressed the positive influence of magnetic fields (MFs) on seed germination (Baghel; Kataria; Guruprasad, 2016; Iqbal et al., 2016; Baghel; Kataria; Guruprasad, 2017). Despite the observed influence of MFs on seeds, an increased knowledge of the effect of MFs in seed physiology is required (Silva; Dobresnski, 2016).

The magnetic pretreatment of coffee seeds to optimize germination is still an emergent process. Alemán et al. (2014) analysed the effects of magnetism on seedlings at different developmental stages and concluded that the application of an electromagnetic field promoted an increase in nutrient absorption from the culture medium. This conclusion was directly correlated with cell metabolism and the energy production necessary for cell division to increase seedling size and development.

Magnetic pretreatment is known as magnetopriming and is used to enhance the germination and vigour of seeds (Rathod; Anand, 2016). Therefore, it is considered an alternative to traditional methods based on chemical products, which are expensive and require human intervention (Araujo et al., 2016).

The main hypothesis of this work is that coffee seeds treated with an MF demonstrate improved germination. Thus, this work exposed coffee seeds to a continuous MF, varying its intensity on two treatments and monitoring the process through traditional tests and a nondestructive optical method.

\section{MATERIAL AND METHODS}

\section{Biological material}

The coffee seeds used in this work were Coffea arabica L., cultivar Catuaí Vermelho 144, from the 2017 harvest, sieve 19. All seeds were harvested while in the cherry stage and subsequently mechanically pulped, with the mucilage removed by fermentation in water. The endocarps were removed manually. The seeds were subjected to a magnetic field for 6 days (Vivas et al., 2016) within a germinator at $30^{\circ} \mathrm{C}$ and $100 \%$ moisture, according to the standard germination test (Brasil, 2009).

Figure 1 demonstrates the distribution and sequence of tests employed for the seeds and the detailed division of seeds per test.

The seeds were removed from the magnetic stimulus after 6 days of $10 \mathrm{mT}$ or $28 \mathrm{mT}$ MF exposure within the germinators and analysed according to different tests.

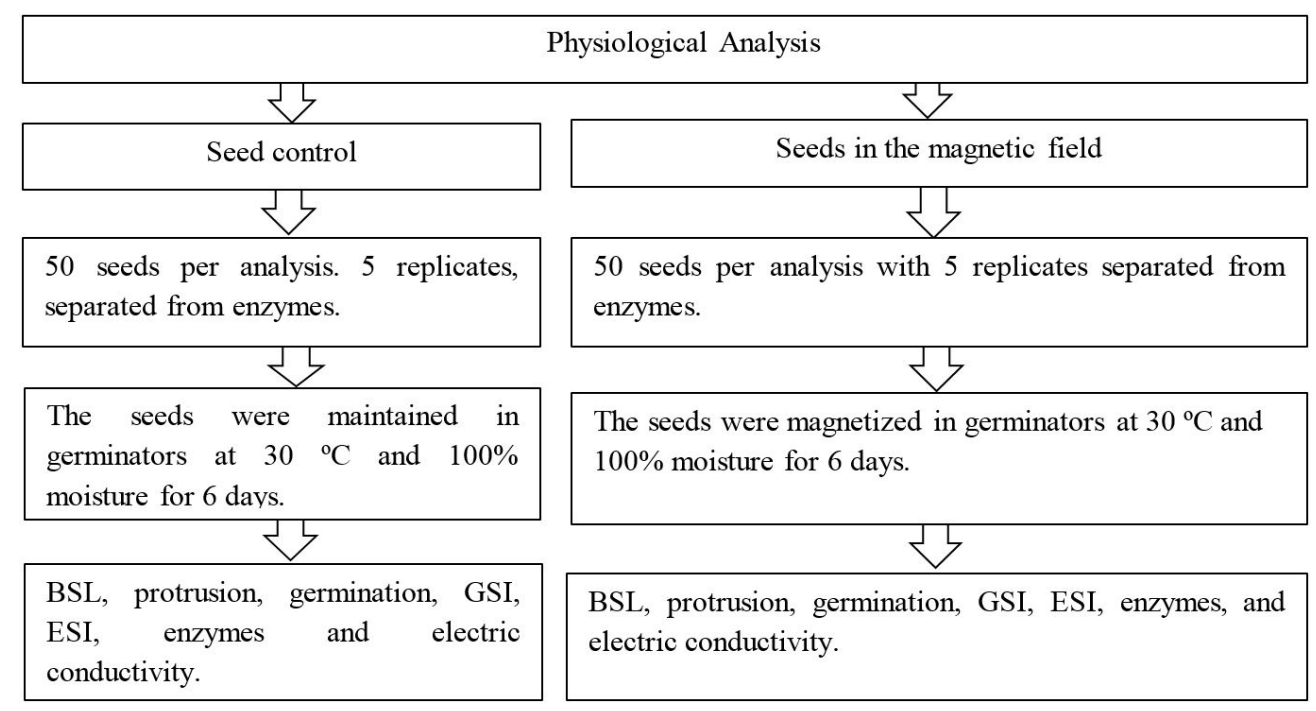

Figure 1: Dynamics of Analysis. 


\section{Magnetic treatment of the seeds}

The seeds were magnetically treated using permanent magnets, as shown in Figure 2. The intensity of the field was obtained by coupling magnets. Two fields, $10 \mathrm{mT}$ and $28 \mathrm{mT}$, were set and verified using a Gaussian meter (MGM 20) to assure the intensity and homogeneity with the permanent magnet.

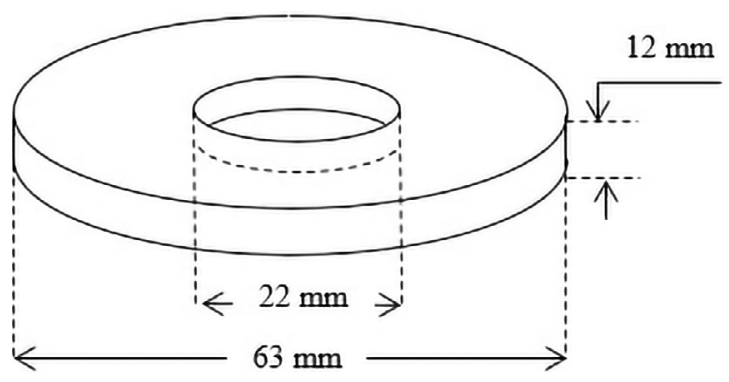

Figure 2: Dimensions of the Permanent Magnet.

The seeds were placed in the central hole of the permanent magnetic field (Figure 2) within an envelope in the form of a strip made of Germitest paper, as shown in Figure 3. The strip presented an individual placement for each seed, totalling 50 placements. The seeds were placed in the strip with the embryo always facing the south pole of the magnet. The orientation of the seeds with the embryo towards the south magnetic pole was intuitive since the magnetic field works on moving electrical loads, as is the case for the ions. Thus, for those ions that were already directed to the embryonal region, they would not deviate in their path. Lorentz's law guarantees that electric loads that displace in the direction of a magnetic field do not suffer from deviations by electric force, remembering that a field's direction moves from the north pole to the south pole.

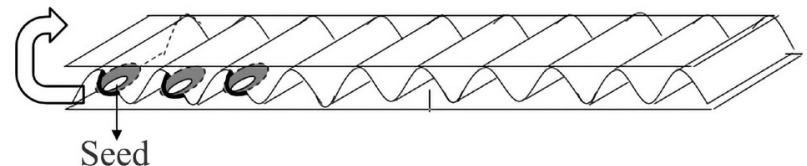

Figure 3: Germitest moistened paper built in a strip with envelopes for placing the seeds.

The strips were curled up, forming a cylinder to be inserted into the hole (Figure 4). The paper with the seeds placed inside the envelopes was moistened to 2.5 times the weight of the dry paper with distilled water.

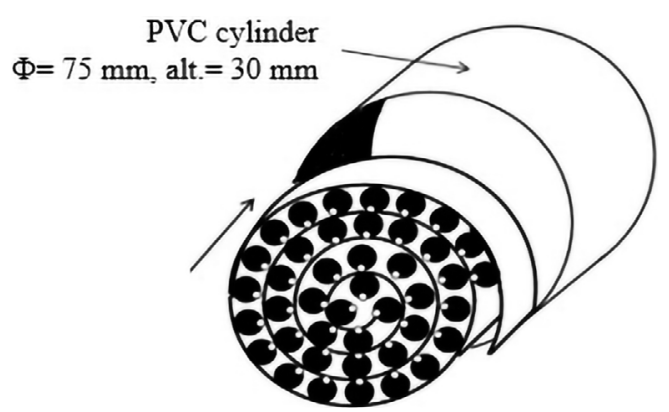

Figure 4: Curled strip with the seeds inside.

The cylinders with the seeds were placed in two germinators, one as a control and the other with the magnets.

\section{Optical test - biospeckle laser index}

On the $6^{\text {th }}$ day of germination, 750 seeds $(250$ for each treatment) were removed from the germinators and analysed using the biospeckle laser technique (Vivas et al., 2016), as presented in Figure 5. A biospeckle laser was used as a supplemental test to physiologically measure embryonic activity without destroying the seed.

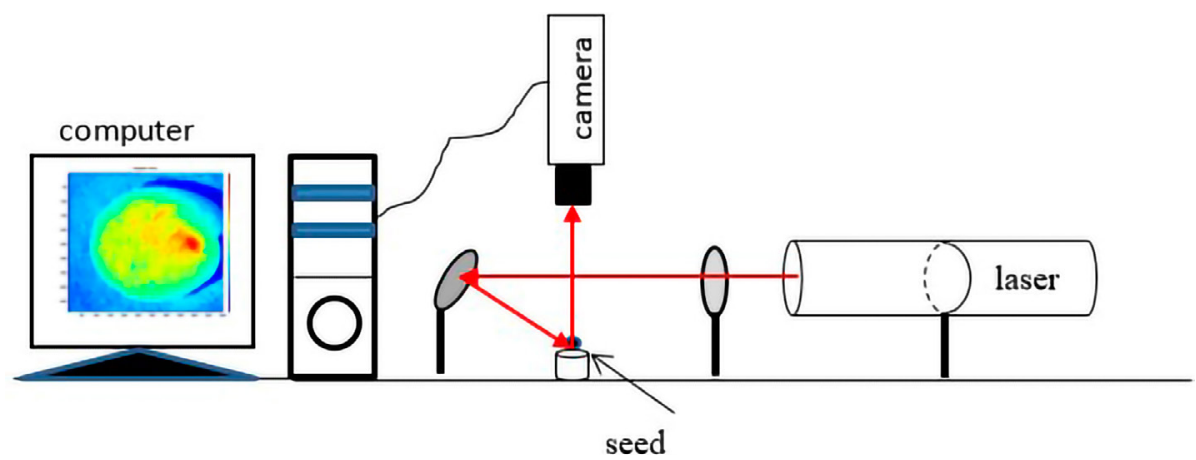

Figure 5: Experimental configuration of the backscattering approach with the optical elements and the image assembly and processing devices. 
The experimental configuration was based on a backscattering approach with a CCD camera (jAi CV-S 3200), a HeNe laser of $632 \mathrm{~nm}$ and $10 \mathrm{~mW}$, a neutral lens, a beam splitter, and mirrors, all installed on an optical table. The images from the illuminated seeds were acquired at $0.08 \mathrm{~s}$ with a resolution of $480-640$ pixels.

Image processing was conducted using numerical methods and the biospeckle laser index (BLI). In this case, the inertia moment (IM) (Braga et al., 2001) and absolute value of the differences (AVD) (Arizaga; Trivi; Rabal, 1999) were obtained in the OCTAVE environment using open-source routines (www.nongnu.org./bsltl/).

Equation 1 presents the IM BLS:

$\mathrm{MI}=\sum_{\mathrm{ij}} \mathrm{M}_{\mathrm{ij}}(\mathrm{i}-\mathrm{j})^{2}$

where $M_{i j}$ is the occurrence matrix formed by the time history of the speckle pattern and $i$ and $j$ are the coordinates of the points in the matrix.

Equation 2 presents the AVD BSL:

$\operatorname{AVD}=\sum_{\mathrm{ij}} \mathrm{M}_{\mathrm{ij}}|\mathrm{i}-\mathrm{j}|$

which uses the same occurrence matrix of the IM equation. The numerical methods that presented the level of change in the illuminated seed were applied in the restricted area of the embryo.

\section{Germination test}

For each treatment, 250 seeds were placed in Germitest paper saturated with distilled water at 2.5 times the weight of the dry paper and stored in a germinator at $30^{\circ} \mathrm{C}$. After 30 days, germination was evaluated following the Rules for Seed Analysis (Brasil, 2009).

\section{Root protrusion}

During the germination test, the protrusion test was conducted on the $15^{\text {th }}$ day, counting the number of seeds with roots of at least one millimetre.

\section{Germination Speed Index (GSI)}

During the germination test, the germination speed index was evaluated by daily observation of the seeds regarding the percentage of germination. The daily index was obtained by dividing the number of germinations by the number of days monitored and the total index obtained by the total sum.

\section{Emergence Speed Index (ESI)}

We distributed 250 seeds from each treatment into plastic boxes filled with a mixture of sand and soil in a proportion of 2:1, which was stored in a growth chamber at $30{ }^{\circ} \mathrm{C}$. The boxes were moistened every 2 days and limited to $70 \%$ of the substrate field capacity. The ESI was obtained using the protocol proposed by Maguire (1962), and the data obtained were the daily count of emerged seedlings.

\section{Enzyme analysis}

Complimentary analyses were conducted to validate the traditional germination tests and were based on the enzyme expression of catalase (CAT), superoxidedismutase (SOD), esterase (EST), malate dehydrogenase $(\mathrm{MDH})$ and endo- $\beta$-mannanase (END) enzymes. We prepared 50 seeds for each enzyme, which were ground and placed in microtubes to receive $300 \mu \mathrm{L}$ of extraction buffer (50 mM tris-HCl-7.5; $500 \mathrm{mM} \mathrm{NaCl} ; 5 \mathrm{mM} \mathrm{MgCl}_{2}$; $1 \mathrm{mM}$ PMSF) and an antioxidant in a proportion of $5 \mathrm{mg}$ to each $\mathrm{mL}$ of buffer. The tubes were placed in a vortex and centrifuged at $14.000 \mathrm{~g}$ for $20 \mathrm{~min}$ at $40{ }^{\circ} \mathrm{C}$.

The supernatant was incubated in a water bath at $85{ }^{\circ} \mathrm{C}$ for 15 minutes and centrifuged again for 30 minutes. The supernatant was placed in microtubes, and the pellet was discarded. Prior application, the microtubes containing $45 \mathrm{~mL}$ protein extract $+23 \mathrm{~mL}$ sample buffer ( $5 \mathrm{~mL}$ glycerol, $2.5 \mathrm{~mL}$ concentrating gel buffer solution, $2.5 \mathrm{~mL}$ bromophenol blue, completing the volume with distilled water) were placed in a boiling bath for 5 minutes. Subsequently, $40 \mu \mathrm{L}$ of each sample was added to polyacrylamide gel SDS-PAGE at $12.5 \%$ (separating gel) and $6 \%$ concentrating gel. The revelation for detecting the isoenzymes was conducted according to the methodology described by Alfenas et al. (2006).

The extraction of the endo- $\beta$-mananase enzyme was performed using 50 ground seeds from each treatment, mixing $200 \mathrm{mg}$ of the ground material with $600 \mu \mathrm{l}$ extraction buffer $(0.1 \mathrm{~m}$ hepes $/ 0.5 \mathrm{~m} \mathrm{NaCl}$ and $9.5 \mathrm{mg}$ ascorbic acid per $\mathrm{ml}$ of buffer solution) at a $\mathrm{pH}$ of 8.0. The samples were centrifuged for $30 \mathrm{~min}$ at $10000 \mathrm{~g}$, and $2 \mu \mathrm{L}$ of the supernatant was applied to a gel containing 6 $\mathrm{mL}$ of LBG (Locust Bean Gum), $0.24 \mathrm{~g}$ agarose, and 24 $\mathrm{mL} 5.0 \mathrm{pH}$ buffer $\left(1 \mathrm{M}\right.$ citric acid/ $\left.0.4 \mathrm{M} \mathrm{Na}_{2} \mathrm{HPO}_{4} .2 \mathrm{H}_{2} \mathrm{O}\right)$. The aliquots were placed in $2 \mathrm{~mm}$ holes on the gel. The gel was incubated for 21 hours and revealed according to the methodology proposed by Silva et al. (2005). The activity of the endo- $\beta$-mananase enzyme was calculated according to Downie, Hilhorst and Bewley (1994). 
After acquiring the traditional image of the enzyme expression, such as the one presented in Figure 6, the images were digitally processed using a threshold (Figure 7) and area count (in pixels ${ }^{2}$ ) for each treatment.

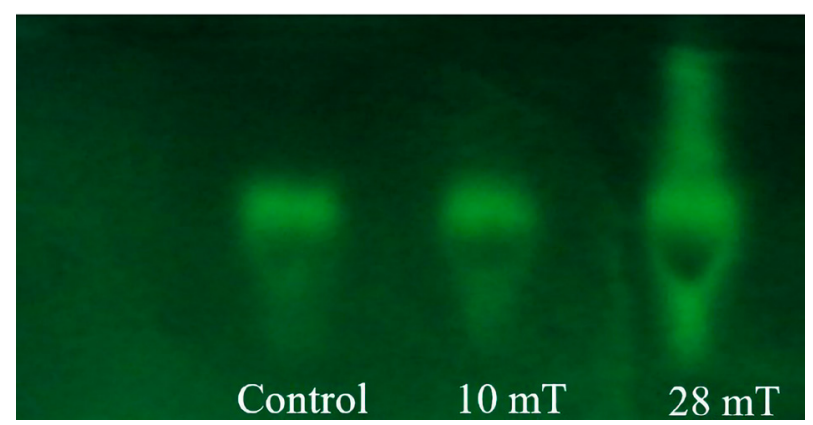

Figure 6: Example of the expression of the CAT enzyme in three treatments; control, $10 \mathrm{mT}$, and $28 \mathrm{mT}$.

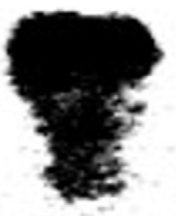

Control

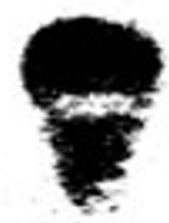

$10 \mathrm{mT}$

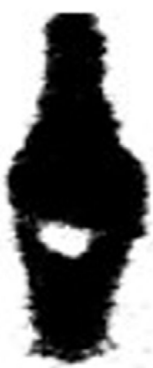

$28 \mathrm{mT}$
Figure 7: Example of digital image processing using a threshold.

\section{Electrical conductivity test}

The electrical conductivity tests were performed using 250 seeds from each treatment (50 seeds with 5 replicates). We placed 50 seeds in plastic cups with $75 \mathrm{ml}$ of distilled water and later transferred them to a BOD at $25{ }^{\circ} \mathrm{C}$ for 96 hours. The measurements were performed using a conductivimeter (DIGIMED CD-21).

\section{Statistical Analysis}

The statistical design was completely randomized and compared three treatments of magnetic field exposure (control, intensities of $10 \mathrm{mT}$ and $28 \mathrm{mT}$ ), with five replicates of 50 seeds. Statistical analyses were performed using variance analysis with the aid of Sisvar ${ }^{\circledR}$ software (Ferreira, 2014) at $5 \%$ probability by the $F$ test $(p<0.05)$. The averages were analysed using the Tukey test at $5 \%$.

\section{RESULTS AND DISCUSSION}

\section{BSL analysis}

Table 1 shows the numerical values for the BSL, AVD and IM of the embryos after 6 days in the germinators. The Tukey test at $5 \%$ probability indicated that the BSL can statistically distinguish the elevation of the activity in the treatments submitted to magnetization when compared to the control seeds. The IM values were also sensitive to the changes caused by the magnetization treatments.

Table 1: Statistical results of the BSL, AVD and IM indexes for three treatments.

\begin{tabular}{cccc}
\hline Treatments & AVD & Treatments & IM \\
\hline Control & $16.726 \mathrm{~b}$ & Control & $460.712 \mathrm{c}$ \\
$10 \mathrm{mT}$ & $22.729 \mathrm{a}$ & $10 \mathrm{mT}$ & $673.473 \mathrm{~b}$ \\
$28 \mathrm{mT}$ & $22.795 \mathrm{a}$ & $28 \mathrm{mT}$ & $857.816 \mathrm{a}$ \\
\hline
\end{tabular}

Mean values followed by the same letter in the column do not differ by the Tukey test at 5\% probability.

Since the BSL is based on the entire biological activity of the seed, all the changes caused by enzyme activation were summed into one index.

Furthermore, as a non-destructive test that can be conducted after only 6 days of magnetization, it can reduce time consumption and costs for the analysis.

\section{Germination test}

The seeds submitted to the magnetic field presented higher germination rates than the control (Table 2). There was no significant difference in germination between the treated seeds using MF, but there was a significant difference between the treated and untreated seeds (control).

Table 2: Statistical results of germination (\%).

\begin{tabular}{cc}
\hline Treatments & Germination (\%) \\
\hline Control & $39.500 \mathrm{~b}$ \\
$10 \mathrm{mT}$ & $66.500 \mathrm{a}$ \\
$28 \mathrm{mT}$ & $70.500 \mathrm{a}$ \\
\hline
\end{tabular}

Mean values followed by the same letter do not differ by the Tukey test at 5\% probability.

The significant difference between the treated seeds using the magnetic field and those without treatment was presented by Osorio, Aranzazu-Osorio and Carbonell- 
Padrino (2015), who used magneto priming in tomato and soybean seeds. The same result was achieved by Menegatti et al. (2019) in passion fruit seeds.

The magneto-priming technique increased germination speed compared to the control treatment (no exposure of seeds to MF), suggesting a certain influence of MFs on the processes of water absorption by seeds, a fact that may have resulted in increased speed and uniformity of the germination process (Osorio; Aranzazu-Osorio; Carbonell-Padrino, 2015). The alteration of the water properties (with greater circulation capacity) and the possible action on the cell membrane permeability allow elucidation of the mechanism of magnetic field action on seed germination promotion (Menegatti et al., 2019).

\section{Protrusion}

The protrusion of seeds presented the same behaviour as the germination test, with the two magnetic field treatments presenting higher protrusion than the control (Table 3).

Table 3: Statistical results of protrusion (\%).

\begin{tabular}{cc}
\hline Treatments & Protrusion mean \\
\hline Control & $71.500 \mathrm{~b}$ \\
$10 \mathrm{mT}$ & $83.500 \mathrm{a}$ \\
$28 \mathrm{mT}$ & $87.000 \mathrm{a}$ \\
\hline
\end{tabular}

Mean values followed by the same letter do not differ by the Tukey test at $5 \%$ probability.

These results support the hypothesis suggested by Tai, Wu and Chang (2008) that the exposure of seeds to a magnetic field increases the capacity of water movement in the substrate and inside the organ, facilitating the imbibition process and promoting the resumption of embryo growth and development more quickly.

\section{Germination Speed Index (GSI)}

The GSI followed the tendency of the germination and protrusion tests, indicating the influence of MF on the increase in seed germination. These results are highly expected since these tests are closely connected to the same germination process (Table 4).

Menegatti et al. (2019) addressed the effects of magnetic fields on the germination index GSI and obtained a $36.94 \%$ higher GSI for seeds submitted to magneto priming.
Table 4: Statistical results of GSI.

\begin{tabular}{cc}
\hline Treatments & GSI Mean \\
\hline Control & $4.185 \mathrm{~b}$ \\
$10 \mathrm{mT}$ & $4.991 \mathrm{a}$ \\
$28 \mathrm{mT}$ & $5.155 \mathrm{a}$ \\
\hline
\end{tabular}

Mean values followed by the same letter do not differ by the Tukey test at 5\% probability.

The positive influence of the MF on the germination rate was also observed by Florez, Carbonell and Martine (2007) in maize seeds.

\section{Emergency Speed Index - ESI}

The ESI demonstrated the influence of the MF on seed germination only when adopting the highest value $(28 \mathrm{mT})$ of the magnetic field. Thus, the $10 \mathrm{mT}$ field presented the same result as the control from the statistical perspective of the ESI (Table 5).

Table 5: Statistical results of ESI.

\begin{tabular}{cc}
\hline Treatments & ESI \\
\hline Control & $0.485 \mathrm{~b}$ \\
$10 \mathrm{mT}$ & $0.557 \mathrm{~b}$ \\
$28 \mathrm{mT}$ & $0.777 \mathrm{a}$ \\
\hline
\end{tabular}

Mean values followed by the same letter do not differ by the Tukey test at 5\% probability.

Figure 8 shows the difference between the number of developing seedlings for all three treatments at the same interval of time.

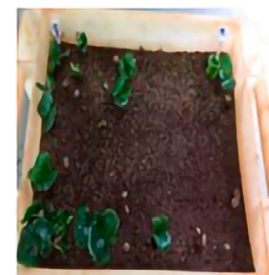

(a)

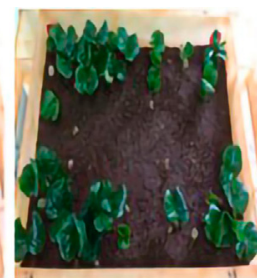

(b)

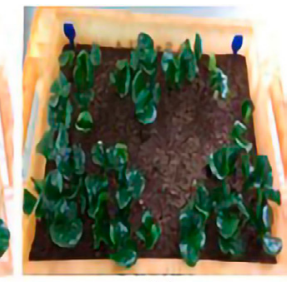

(c)
Figure 8: Comparison of the seedlings for treatments: (a) control, (b) $10 \mathrm{mT}$, and (c) $28 \mathrm{mT}$ on the seventysixth day of sowing.

Aghamir et al. (2015) and Aguilera and Martín (2016) observed that magnetized water used in the irrigation 
of maize seeds increased the physiological features related to germination compared to the control seeds without magnetized water.

In relation to the potential of MF to change the properties of water to make it more mobile and improve its action on the permeability of cell membranes, thus facilitating the transport of ions and water, it is noteworthy that the exposure of coffee seeds to MF provided higher performance regarding seed germination and emergence when compared to the seeds not exposed to MF.

\section{Enzyme tests}

Catalase - CAT

The CAT enzyme presented an electrophoretic pattern highly accentuated in the seeds submitted to the MF. The areas of enzyme expression were obtained by image processing and were used to compare the influence of the MF on seed germination. The numerical values are presented in Figure 9, where the expressions of the $10 \mathrm{mT}$ and $28 \mathrm{mT}$ treatments were 1.17 and 1.92 times that of the control, respectively. Thus, the higher the MF strength is, the higher the generation of free radicals, especially $\mathrm{H}_{2} \mathrm{O}_{2}$, indicating oxidation stress that forces the activation of the catalase enzyme as a defence response.

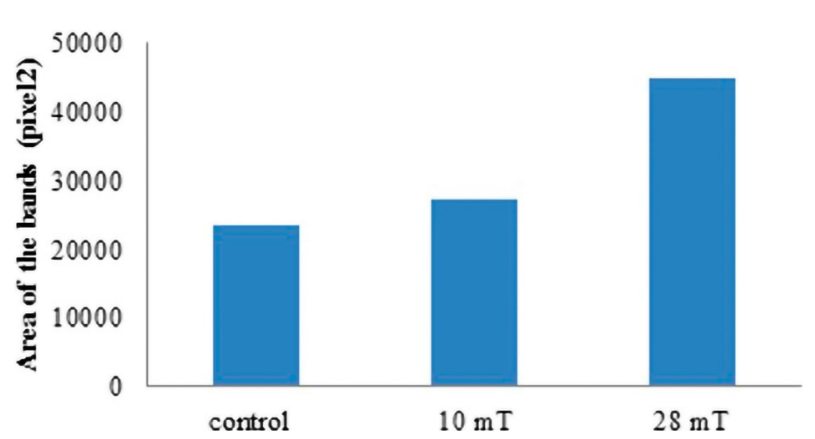

Figure 9: Quantification of catalase enzyme expression area.

Puntarulo and Boveris (1990) confirmed the increase in the production of catalase as a response to accelerated ageing that is also related to free-radical stress. Similarly, there are reports connecting free radicals to scavenging enzymes such as catalase.

\section{Superoxide dismutase (SOD)}

The enzyme superoxide dismutase (SOD) presented higher activity as a result of the increase in the intensity of the MF. A similar digital image processing was conducted with the enzyme expression bands and areas in pixel ${ }^{2}$ in the treatments, which is demonstrated in Figure 10. As occurs with CAT, the SOD enzyme presented an increase in the expression band as a response to both MFs, at a rate of 1.22 for $10 \mathrm{mT} /$ control and 1.52 for $28 \mathrm{mT} /$ control.

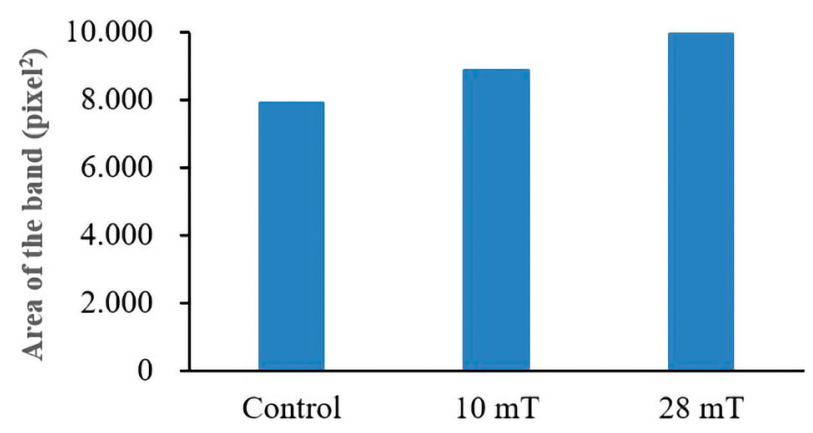

Figure 10: Quantification of SOD enzyme expression area.

Goel, Goel and Sheoran (2003) reported that the decrease in the expression of SOD in seeds was connected to its loss of viability. Therefore, an increase in the expression of SOD due to MF can be connected to the increase in germination, as expected and observed.

\section{Esterase (EST)}

The enzyme esterase was only positively affected by the $28 \mathrm{mT}$ field, while in the $10 \mathrm{mT}$ field, its expression was reduced by half (Figure 11). Since the enzyme esterase is inversely connected to the integrity of the phospholipid membranes, the $28 \mathrm{mT}$ MF increased the expression of esterase 2.45 times, thus increasing membrane rupture and the amount of leachate.

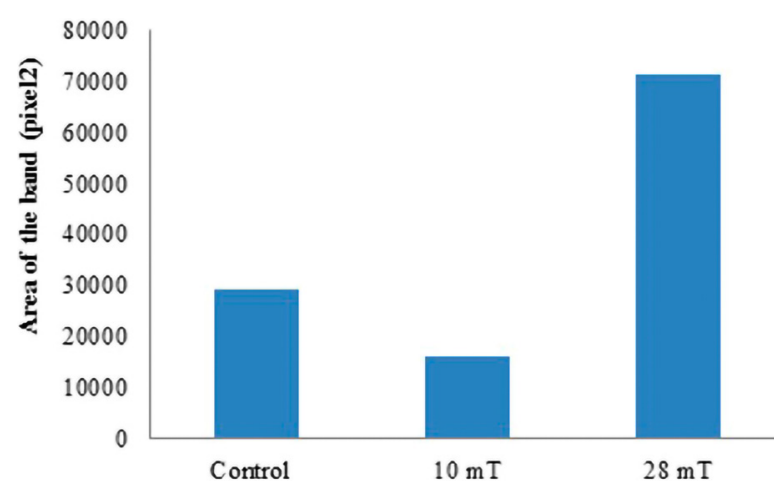

Figure 11: Quantification of the esterase enzyme expression area. 
Both enzymes play a key role in the germination process. The decrease in the expression of esterase caused by the $10 \mathrm{mT}$ field cannot be explained by the data we obtained. However, Chauhan, Gopinathan and Babu (1985) observed a positive correlation between esterase and membrane disruption.

\section{Malate dehydrogenase (MHD)}

The change in the expression of MHD was positively correlated with the MF, where the areas in pixel ${ }^{2}$ provided by the image processing increased at a rate of 1.03 times from the control to $10 \mathrm{mT}$ and 1.08 times from the control to $28 \mathrm{mT}$ (Figure 12).

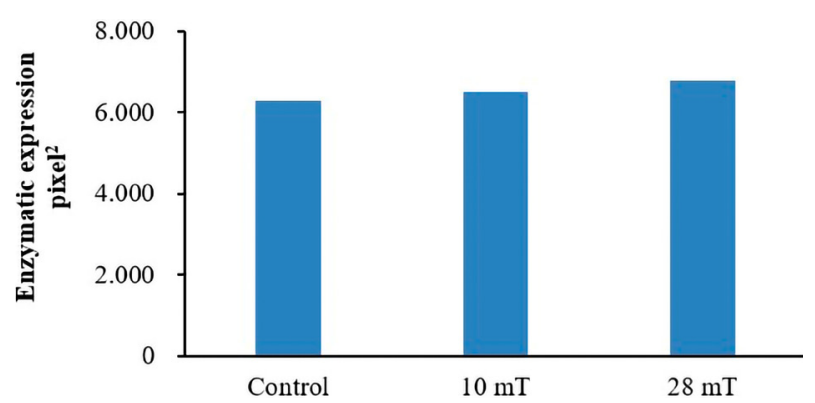

Figure 12: Quantification of the malate dehydrogenase enzyme expression area.

\section{Endo-ß-mannanase}

The endo- $\beta$-mananase enzyme is directly connected to coffee germination at an early stage. This enzyme can degrade the walls around the embryo, thus helping in the emergence of the radicle (Silva et al., 2005). Figure 13 shows the activity of the endo- $\beta$-mananase enzyme present in all three treatments. The expression of the enzyme is connected to the diameter of the circle, which was digitally measured.

Downie, Hilhorst and Bewley (1994) reported that the diameter of the light circle is inversely proportional to the enzyme activity; thus, we obtained the circular areas digitally based on Table 6 and Figure 13 .

Table 6: Endo- $\beta$-mananase enzyme activity in $\mathrm{pmol} \mathrm{min}^{-1} \mathrm{~g}^{-1}$.

\begin{tabular}{cc}
\hline Treatments & Activity \\
\hline Control & $140179.056 \mathrm{c}$ \\
$10 \mathrm{mT}$ & $200980.573 \mathrm{~b}$ \\
$28 \mathrm{mT}$ & $335546.313 \mathrm{a}$ \\
\hline
\end{tabular}

Mean values followed by the same letter do not differ by the Tukey test at 5\% probability.

The enzyme endo- $\beta$-mananase was sensitive to the MF and caused a separation of the three treatments. The increase in germination speed due to the influence of the MF in the seeds also influenced the activity of the enzyme endo$\beta$-mananase to degrade cell walls for radicular protrusion, showing a direct correlation with the physiological results.

\section{Electric conductivity}

The electrical conductivity was only reduced by a magnetic field of $10 \mathrm{mT}$ (Table 7). The lower electrical conductivity at the MF intensity of $10 \mathrm{mT}$ is in line with the result obtained with the electrophoretic expression of the EST enzyme, for which the lowest activity was for the $10 \mathrm{mT}$ magnetization, indicating a better organization of plasma membrane structure.

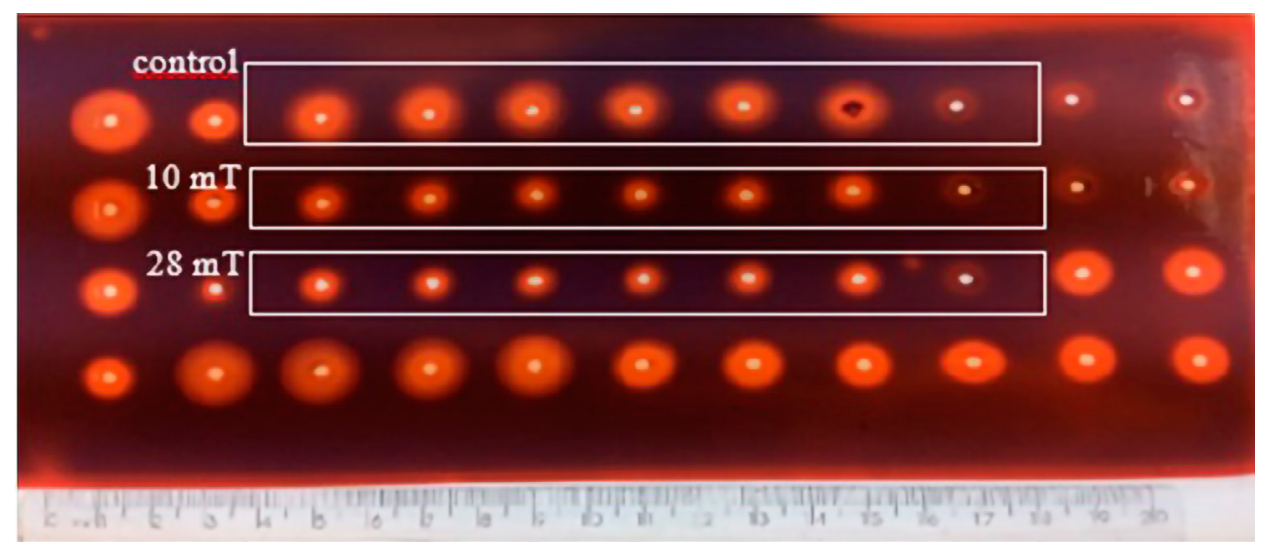

Figure 13: Expression of the endo- $\beta$-mananase enzyme. 
Table 7: Mean values of electrical conductivity in $\mu \mathrm{S}$ $\mathrm{cm}^{-1} \mathrm{~g}^{-1}$.

\begin{tabular}{cc}
\hline Treatments & Electrical conductivity means \\
\hline Control & $22.002 \mathrm{~b}$ \\
$10 \mathrm{mT}$ & $12.460 \mathrm{a}$ \\
$28 \mathrm{mT}$ & $17.264 \mathrm{~b}$ \\
\hline
\end{tabular}

Mean values followed by the same letter do not differ by the Tukey test at 5\% probability.

\section{CONCLUSIONS}

Biospeckle laser monitoring was efficient in detecting differentiated embryonic activity due to the exposure of the seeds to the magnetic fields. The magnetization of coffee seeds is efficient for reducing the germination period, regardless of the values of the magnetic field. The magnetization of coffee seeds is a promising process in the pregermination conditioning of coffee seeds in view of the results obtained. For both magnetic field intensities, there were both beneficial and deleterious effects on the germination process. However, the harmful effects were not significant in the germination process. The magnetization process can be inexpensive, functional, and replicable outside laboratory situations.

\section{REFERENCES}

AGHAMIR, F. et al. Magnetized water effects on seed germination and seedling growth of corn (Zea mays) under saline conditions. American Journal of Life Science Researches, 3(2):184-195, 2015.

AGUILERA, J. G.; MARTíN, R. M. Água tratada magneticamente estimula a germinação e desenvolvimento de mudas de Solanum lycopersicum L. Revista Brasileira de Agropecuária Sustentável, 6(1):47-53, 2016.

ALEMÁN, E. I. et al. Effects of $60 \mathrm{~Hz}$ sinusoidal magnetic field on in vitro establishment, multiplication, and acclimatization phases of Coffea arabica seedlings. Bioelectromagnetics, 35:414-425, 2014.

ALFENAS, A. C. Eletroforese e marcadores bioquímicos em plantas e microrganismos. 2.ed. Viçosa: Ed. UFV, 2006. 627p.

ARAUJO, S. S. et al. Physical methods for seed invigoration: Advantages and challenges in seed technology. Frontiers in Plant Science, 7:1-12, 2016.

ARIZAGA, R.; TRIVI, M.; RABAL, H. J. Speckle time evolution characterization by the co-occurrence matrix analysis. Optics and Laser Technology, 31(2):163-169, 1999.
BAGHEL, L.; KATARIA, S.; GURUPRASAD, K. N. Static magnetic field treatment of seeds improves carbon and nitrogen metabolismo under salinity stress in soybean. Bioelectromagnetics, 37:455-470, 2016.

BAGHEL, L.; KATARIA, S.; GURUPRASAD, K. N. Effect of static magnetic field pretreatment on growth, photosynthetic performance and yield of soybean under water stress. Photosynthetica, 55:1-13, 2017.

BRAGA, R. A. et al. Potencial do biospecklelaser para avaliação da viabilidade de sementes. Ciência e Agrotecnologia, 25(3):646-649, 2001.

BRASIL. Ministério da Agricultura, Pecuária e Abastecimento. Regras para análise de sementes. Brasília: MAPA-ACS, 2009. 395p.

CHAUHAN, K. P. S.; GOPINATHAN, M. C.; BABU, C. R. Eletrophoretic variations of proteins and enzymes in relation to seed quality. Seed Science and Technology, 13:629-641, 1985.

DIAS, M. C. L. L.; SILVA, W. R. Determinação da viabilidade de sementes de café através do teste de tetrazólio. Pesquisa Agropecuária Brasileira, 21(11):1139-1145, 1986.

DOWNIE, B.; HILHORST, H. W. M.; BEWLEY, J. D. A new assay for quantifying endo- $\beta$-mananase activity using Congo Red dye. Phytochemistry, 36(4):829-835, 1994.

EIRA, M. T. S. et al. Coffee seed physiology. Brazilian Journal of Plant Physiology, 18(1):149-163, 2006.

FERREIRA, D. F. SISVAR: A guide for its bootstrap procedures in multiple comparisons. Ciência e Agrotecnologia, 38(4):278-286, 2014.

FLOREZ, M.; CARBONELL, M. V.; MARTINE, E. Exposure of maize seeds to stationary magnetic fields: Effects on germination and early growth. Environmental and Experimental Botany, 59(3):68-75, 2007.

GOEL, A.; GOEL, A. K.; SHEORAN, I. S. Changes in oxidative stress enzymes during artificial ageing in cotton (Gossypium hirsutum L.) seeds. Journal of Plant Physiology, 160(9):1093-1100, 2003.

GUIMARÃES, G. C. et al. Minimum period to assess the potential of germination of coffee seeds. Journal of Seed Science, 35:347-352, 2013.

IQBAL, M. et al. Pre-sowing seed magnetic field stimulation: A good option to enhance bitter gourd germination, seedling growth and yield characteristics. Biocatalysis Agricultural Biotechnology, 5:30-37, 2016. 
MAGUIRE, J. D. Speed of germination - Aid seedling emergence and vigor. Crop Science, 2(2):176-177, 1962.

MATIELLO, J. B.; GARCIA, W. R.; ALMEIDA, S. R. Renovar mais, Nossos Cafezais. 2009. Available in: <http:// fundacaoprocafe.com.br/downloads/Folha009Renovar. pdf>. Access in: August, 20, 2018.

MENEGATTI, R. D. et al. Magnetic field and gibberelic acid as pre-germination treatments of passion fruit seeds. Ciência Agrícola, 17(1):15-22, 2019.

OSORIO, J. I.; ARANZAZU-OSORIO, J. E.; CARBONELL-PADRINO, M. V. Static homogeneous magnetic field effects on germination and water absorption in soybean seeds. Tecnológicas, 18(35):11-20, 2015.

PUNTARULO, S.; BOVERIS, A. Effects of natural and accelerated aging on the hydroperoxide metabolism of soybean embryonic axes. Plant Sciences, 68:27-32, 1990.
RATHOD, G. R.; ANAND, A. Effect of seed magneto-priming on growth, yield and $\mathrm{Na} / \mathrm{K}$ ratio in wheat (Triticum aestivum L.) under salt stress. Industrial Journal Plant Physiology, 21(1):15-22, 2016.

TAI, C. Y.; WU, C.; CHANG, M. Effects of magnetic field on the crystallization oc calcium carbonate using permanent magnets. Chemical Engineering Science, 63:5606-5612, 2008.

SILVA, J. A. T.; DOBRANSZKI, J. Magnetic fields: How is plant growth and development impacted. Protoplasma, 253:231-248, 2016.

SILVA, E. A. A. et al. Abscisic acid controls embryo growth potential and endosperm cap weakening during coffee (Coffea arabica L., cv. Rubi) seed germination. Planta, 220(2):251-261, 2005.

VIVAS, P. G. et al. Biospeckle activity in coffee seeds is associated non-destructively with seedling quality. Annals of Applied Biology, 1(1):1-9, 2016. 